\title{
Synthesis and some properties of light lanthanide complexes with $4,4^{\prime}$-bipyridine and dibromoacetates
}

\author{
Thermal study
}

\author{
A. Czylkowska
}

Received: 3 September 2012/ Accepted: 4 January 2013/Published online: 26 March 2013

(C) The Author(s) 2013. This article is published with open access at Springerlink.com

\begin{abstract}
In this study, new complexes with formulae: $\mathrm{Ce}(4-$ bpy) $\left(\mathrm{CHBr}_{2} \mathrm{COO}\right)_{3} \cdot \mathrm{H}_{2} \mathrm{O}, \quad \mathrm{Ln}(4-\mathrm{bpy})_{0.5}\left(\mathrm{CHBr}_{2} \mathrm{COO}\right)_{3} \cdot 2 \mathrm{H}_{2} \mathrm{O}$ (where $\mathrm{Ln}(\mathrm{III})=\mathrm{Pr}, \mathrm{Nd}$, Sm; 4-bpy $=4,4^{\prime}$-bipyridine) and $\mathrm{Eu}(4-\mathrm{bpy})\left(\mathrm{CHBr}_{2} \mathrm{COO}\right)_{3} \cdot 2 \mathrm{H}_{2} \mathrm{O}$ were prepared, and characterized by chemical and elemental analyses, and IR spectroscopy. The way of metal-ligand coordination was discussed. They are small crystalline. The complexes of $\mathrm{Pr}(\mathrm{III}), \mathrm{Nd}(\mathrm{III})$, and Sm(III) are isostructural in group. Conductivity studies (in methanol, dimethylformamide, and dimethylsulfoxide) were also performed and described. The thermal properties of complexes in the solid state were studied using TG-DTG techniques under dynamic flow of air atmosphere. TG-MS system was used to analyze principal volatile thermal decomposition and fragmentation products evolved during pyrolyses of $\mathrm{Ce}$ (III) and $\mathrm{Sm}$ (III) complexes in dynamic flow of air atmosphere.
\end{abstract}

Keywords Light lanthanide complexes · 4,4'-Bipyridine · Dibromoacetates · TG-DTG · TG-MS · IR spectra

\section{Introduction}

This article is a continuation of our earlier research on lanthanide complexes with 4,4'-bipyridine (4-bpy) and halogenoacetates. The rare earth compounds containing halogenoacetates have been studied by many authors. They consider mainly the metal-ligand coordination and magnetic behavior. The mixed-ligand complexes of some lanthanides with $2,2^{\prime}$ - or 4,4'-bipyridine and chloroacetates are known, but with only scant information concerning their

\footnotetext{
A. Czylkowska $(\bowtie)$

Institute of General and Ecological Chemistry, Lodz University of Technology, Lodz, Poland

e-mail: agnieszka.czylkowska@p.lodz.pl
}

thermolysis. Several notes of discussed compounds containing halogenoacetates have been summarized in [1-3].

Our resent investigation related to mixed-ligand lanthanide complexes with 4-bpy and di- or trichloroacetates. We obtained compounds of general formulae: $\mathrm{Ln}(4-\mathrm{bpy})_{\mathrm{n}}$ $\left(\mathrm{CHCl}_{2} \mathrm{COO}\right)_{3} \cdot m \mathrm{H}_{2} \mathrm{O}$ [1, 2, 4-7] and $\mathrm{Ln}(4-\mathrm{bpy})_{\mathrm{n}}\left(\mathrm{CCl}_{3}\right.$ $\mathrm{COO})_{3} \cdot m \mathrm{H}_{2} \mathrm{O}[1,3,8,9]$ in series $\mathrm{Ln}(\mathrm{III})=\mathrm{Y}, \mathrm{La} \rightarrow \mathrm{Lu}$ (without $\mathrm{Pm}$ ). They were characterized by elemental analysis, molar conductivity, and IR spectra. Their thermal behaviors were also studied. The way of metal-ligand coordination was discussed. The chloroacetate groups link with rare earth elements in many different ways. In case of La(III) [4] and Sm(III) [5] compounds, dichloroacetate groups coordinate as chelating tridentate and bridging ligands, and in other compounds [2] as bidentate chelating and monodentate ions. In all compounds 4-bpy joins with lanthanide by one nitrogen atom (only in complexes Er(III), Tb(III), and Lu(III), also half molecule of 4-bpy lies in outer coordination sphere [2]). In the literature, there is not much information about lanthanide complexes with bipyridine isomers and dibromoaceates. Thermal studies of compounds with empirical formulae $\operatorname{Ln}(2-b p y)$ $\left(\mathrm{CHBr}_{2} \mathrm{COO}\right)_{3} \cdot m \mathrm{H}_{2} \mathrm{O}$ where $\mathrm{Ln}(\mathrm{III})=\mathrm{Nd}$, Er were characterized in [10]. In one of our previous articles, we have described preparation and some behaviors of La(III) and Y(III) complexes with title ligands [11]. In this work, we present the synthesis, some physicochemical properties, and thermal studies of new compounds of light rare earth elements with 4-bpy and dibromoacetates. These studies of lanthanide(III) complexes with 4,4'-bipyridine and halogenoacetates allow us to determinate the influence on the kinds of forming complexes, their properties, and thermal decomposition dependent on the type of halogen atoms in carboxylates. 


\section{Experimental}

Materials, synthesis, and analysis

4,4'-bipyridine, $\mathrm{CHBr}_{2} \mathrm{COOH}, \mathrm{Ln}_{2} \mathrm{O}_{3}$ (where $\mathrm{Ln}(\mathrm{III})=\mathrm{Nd}$, $\mathrm{Sm}, \mathrm{Eu}), \quad \mathrm{Pr}_{6} \mathrm{O}_{11}, \mathrm{Ce}\left(\mathrm{NO}_{3}\right)_{3} \cdot 6 \mathrm{H}_{2} \mathrm{O}$, dimethylsulfoxide (DMSO), dimethylformamide (DMF), and methanol (MeOH) (anhydrous) p.a. were obtained from Aldrich and Lab-Scan. Water solutions of metal(III) dibromoacetates were prepared by adding $2 \mathrm{~mol} \mathrm{~L}^{-1}$ dibromoacetic acid to freshly precipitated hydroxides (or freshly precipitated cerium(III) carbonate) in ca. stoichiometric quantities. (in temperature $\leq 18{ }^{\circ} \mathrm{C}$, because lanthanide dibromoacetates in solution are relatively unstable; in presence of 4-bpy their stability arise).

The mixed-ligand complexes were synthesized by reaction of freshly obtained solutions of appropriate $\mathrm{Ln}$ (III) dibromoacetaes with solutions of 4-bpy $(\mathrm{pH} \sim 5)$. The molar ratio of $\mathrm{M}(\mathrm{III})$ :4-bpy was 1:2. Solution of 4-bpy in $31.3 \mathrm{~mL}$ of $96 \% \mathrm{v} / \mathrm{v}$ ethanol $(12.4 \mathrm{mmol})$ was added to $8.7 \mathrm{~mL}$ of water solution of $\mathrm{Ln}(\mathrm{III})$ dibromoacetates $(6.2 \mathrm{mmol})$. The products were washed in $40 \% \mathrm{v} / \mathrm{v}$ ethanol and then in ethanol and diethyl ether mixture (1:1). All compounds were dried in open air. The contents of meta1(III) ions in obtained solutions were mineralized and determined by EDTA titration.

The carbon, hydrogen, and nitrogen contents in the prepared complexes were determined using a Carbo-Erba analyzer with $\mathrm{V}_{2} \mathrm{O}_{5}$ as an oxidizing agent.

Methods and instruments

IR spectra were recorded using a NICOLETT 6700 Spectrometer (4000-400 $\mathrm{cm}^{-1}$ with accuracy of recording $1 \mathrm{~cm}^{-1}$ ) using $\mathrm{KBr}$ pellets. Molar conductance was measured on conductivity meter of the OK-102/1 type equipped with an OK-902 electrode at $25 \pm 0.5{ }^{\circ} \mathrm{C}$, using $1 \times 10^{-3} \mathrm{~mol} \mathrm{~L}^{-1}$ solutions of complexes in methanol, dimethylformamide, and dimethylsulfoxide. The thermal properties of complexes in air were studied by TG-DTG techniques in the range of temperature $25-1000{ }^{\circ} \mathrm{C}$ at a heating rate of $10{ }^{\circ} \mathrm{C} \mathrm{min}{ }^{-1}$; TG and DTG curves were recorded on Netzsch TG 209 apparatus in flow of dynamic air atmosphere $\mathrm{v}=20 \mathrm{~mL} \mathrm{~min}{ }^{-1}$ using ceramic crucibles. The TG-MS coupled measurements have been carried out only for Ce(III) and Sm(III) complexes using the Netzsch TG 209 apparatus coupled with Netzsch MS spectrometer, in the range of temperature of $25-1000{ }^{\circ} \mathrm{C}$ at a heating rate $10{ }^{\circ} \mathrm{C} \mathrm{min}^{-1}$ in flow of air atmosphere $\mathrm{v}=20 \mathrm{~mL} \mathrm{m^{-1 }}$ in ceramic crucibles. The $m / z$ values are given based on ${ }^{1} \mathrm{H}$, ${ }^{12} \mathrm{C},{ }^{14} \mathrm{~N},{ }^{16} \mathrm{O}$, and ${ }^{80} \mathrm{Br}$ (additionally ${ }^{13} \mathrm{C}$ and ${ }^{18} \mathrm{O}$ in case of $\mathrm{CO}_{2}$ ). The X-ray powder diffraction patterns of synthesized complexes, and final solid decomposition products in air were recorded on D-5000 diffractometer using Ni-filtered $\mathrm{CuK}_{\alpha}$ radiation. The measurements were carried out in the range of $2 \theta$ angles $2^{\circ}-80^{\circ}$. The obtained results were analyzed using the Powder Diffraction File [12].

\section{Results and discussion}

Table 1 presents results of the elemental and chemical analyses of the investigated compounds. They are stable in air in solid state. Single crystals of the investigated complexes were not obtained. The analysis of the X-ray powder diffraction patterns of these compounds reveals that they are small crystalline products and complexes of $\mathrm{Pr}(\mathrm{III}), \mathrm{Nd}(\mathrm{III}), \mathrm{Sm}(\mathrm{III})$ are isostructural in group. The $\mathrm{X}$-ray powder diffraction patterns of the obtained complexes are not in Powder Diffraction File [12]. Figure 1 presents the X-ray powder diffraction patterns for complexes $\mathrm{Ce}(\mathrm{III}), \operatorname{Pr}(\mathrm{III})$ (as an example of isostructural group), and $\mathrm{Eu}(\mathrm{III})$.

The molar conductivities values for complexes in $\mathrm{MeOH}$, DMF, and DMSO are given in Table 1. All complexes in $\mathrm{MeOH}$ and DMF display behaviors intermediate between those of non-electrolytes and 1:1 electrolytes. In DMSO they are electrolyte type 1:1 [13]. In series of lanthanide complexes $\mathrm{Ce}$ (III) $\rightarrow \mathrm{Eu}$ (III) with 4-bpy and dichloroacetates, the molar conductivities in solutions $\mathrm{MeOH}$, DMF, and DMSO have similar values [6]. Relatively low molar conductances in $\mathrm{MeOH}$ and DMF are characteristic for all the complexes compared. They dissociate only to a limited degree in these solutions.

Table 1 Analytical data and molar conductivity in MeOH, DMF, and DMSO for investigated complexes

\begin{tabular}{|c|c|c|c|c|c|c|c|}
\hline \multirow[t]{2}{*}{ Compound } & \multicolumn{4}{|c|}{ Analysis: found (calculated) $/ \%$} & \multicolumn{3}{|c|}{$\Lambda_{\mathrm{M}} / \Omega^{-1} \mathrm{~cm}^{2} \mathrm{~mol}^{-1} ; \mathrm{c}=1 \times 10^{-3} \mathrm{~mol} \mathrm{~L}^{-1}$} \\
\hline & $\mathrm{Ln}$ & $\mathrm{C}$ & $\mathrm{N}$ & $\mathrm{H}$ & $\mathrm{MeOH}$ & DMF & DMSO \\
\hline $\mathrm{Ce}(4-\mathrm{bpy})\left(\mathrm{CHBr}_{2} \mathrm{COO}\right)_{3} \cdot \mathrm{H}_{2} \mathrm{O}$ & $14.61(14.52)$ & $20.00(19.92)$ & $2.82(2.90)$ & $1.34(1.36)$ & 51.0 & 42.0 & 52.0 \\
\hline $\operatorname{Pr}(4-\mathrm{bpy})_{0.5}\left(\mathrm{CHBr}_{2} \mathrm{COO}\right)_{3} \cdot 2 \mathrm{H}_{2} \mathrm{O}$ & $15.49(15.56)$ & $14.69(14.60)$ & $1.60(1.55)$ & $1.21(1.22)$ & 47.0 & 47.0 & 55.0 \\
\hline $\mathrm{Nd}(4-\mathrm{bpy})_{0.5}\left(\mathrm{CHBr}_{2} \mathrm{COO}\right)_{3} \cdot 2 \mathrm{H}_{2} \mathrm{O}$ & $15.91(15.87)$ & $14.46(14.54)$ & $1.59(1.54)$ & $1.20(1.22)$ & 50.3 & 40.9 & 51.3 \\
\hline $\mathrm{Sm}(4-\mathrm{bpy})_{0.5}\left(\mathrm{CHBr}_{2} \mathrm{COO}\right)_{3} \cdot 2 \mathrm{H}_{2} \mathrm{O}$ & $16.51(16.43)$ & $14.37(14.44)$ & $1.51(1.53)$ & $1.20(1.21)$ & 45.0 & 37.4 & 50.5 \\
\hline $\mathrm{Eu}(4-\mathrm{bpy})\left(\mathrm{CHBr}_{2} \mathrm{COO}\right)_{3} \cdot 2 \mathrm{H}_{2} \mathrm{O}$ & $15.37(15.28)$ & $19.26(19.32)$ & $2.88(2.82)$ & $1.31(1.32)$ & 44.2 & 36.4 & 49.8 \\
\hline
\end{tabular}




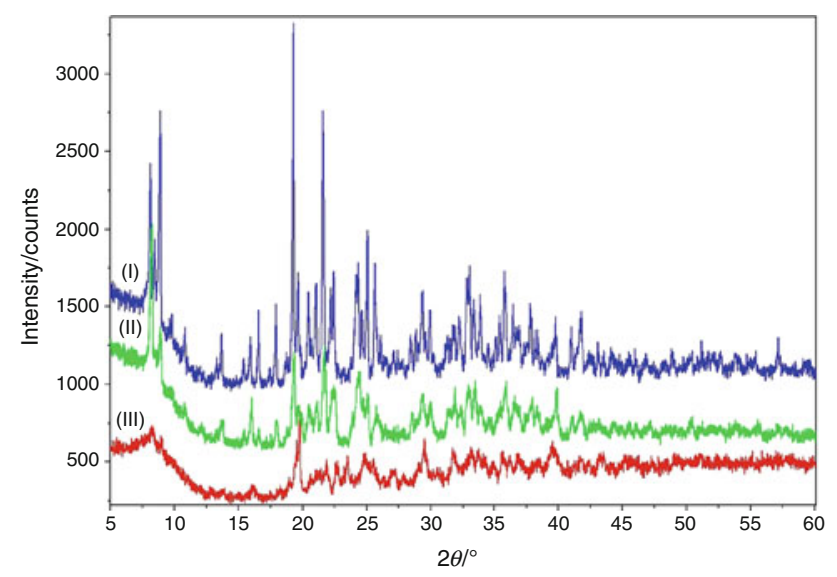

Fig. 1 X-ray powder diffraction patterns for complexes $\mathrm{Ce}(4-$ bpy) $\left(\mathrm{CHBr}_{2} \mathrm{COO}\right)_{3} \cdot \mathrm{H}_{2} \mathrm{O}(\mathrm{I}), \operatorname{Pr}(4-\text { bpy })_{0.5}\left(\mathrm{CHBr}_{2} \mathrm{COO}\right)_{3} \cdot 2 \mathrm{H}_{2} \mathrm{O}(\mathrm{II})$ and $\mathrm{Eu}$ (4-bpy) $\left(\mathrm{CHBr}_{2} \mathrm{COO}\right)_{3} \cdot 2 \mathrm{H}_{2} \mathrm{O}$ (III)

IR spectra

IR spectra of the all fine-crystalline solids show several absorption bands in the region characteristic for dibromoacetates and 4-bpy (Tables 2 and 3). These spectra are very similar, only the asymmetric $v_{\mathrm{as}}(\mathrm{COO})$ band of carboxylate groups in $\mathrm{Eu}(\mathrm{III})$ complex is spitted into two clearly separated bands (1706 and $\left.1674 \mathrm{~cm}^{-1}\right)$. In the case of $\mathrm{Ce}(\mathrm{III}), \operatorname{Pr}(\mathrm{III}), \mathrm{Nd}(\mathrm{III})$, and $\mathrm{Sm}(\mathrm{III})$ compounds, the $v_{a s}(\mathrm{COO})$ vibration is identified as the strong band in the range of $1671-1667 \mathrm{~cm}^{-1}$. The band observed at $1386 \mathrm{~cm}^{-1}$ has been assigned to the vibration of $v_{\mathrm{s}}(\mathrm{COO})$ for all complexes. Using the magnitude of $\Delta v$ as spectral criterion [16] for determination of mode of bonding carboxylate groups in the obtained compounds, suggest that dibromoacetates in series $\mathrm{Ce}(\mathrm{III}) \rightarrow \mathrm{Sm}(\mathrm{III})$ act probably as monodentate ligands. The splitting of $v_{\text {as }}(\mathrm{COO})$ band exists in the spectra of $\mathrm{Eu}(\mathrm{III})$ compound is probably caused by formation of noncompletely equivalent bonds between $\mathrm{Eu}(\mathrm{III})$ carboxylate groups (Table 2) $[17,18]$. On the other hand, in all the obtained complexes, the vibrations $v_{\text {as }}(\mathrm{COO})$ and $v_{\mathrm{s}}(\mathrm{COO})$ are shifted to higher wave numbers corresponding to $\mathrm{CHBr}_{2} \mathrm{COONa}$. According to Manhas and Trikha [19] and [20], these bathochromic shifts are evidence leading to the interpretation that the carboxylate groups are bonded to metal(III) as bridging ligands. However, interpretation the nature of bonding lanthanide(III)-carboxylates is difficult. Different types of coordination carboxylate groups to lanthanide ion in one complex and intramolecular hydrogen bonds $\mathrm{O}$ (water)- $\mathrm{H} \cdots \mathrm{O}$ (carboxyl) may exist $[2,4,5]$. In the absorption region of $\mathrm{CHBr}_{2} \mathrm{COONa}$ appears also the stretching modes $v_{\mathrm{s}}\left(\mathrm{CBr}_{2}\right)$ and $\delta(\mathrm{CCOO})$. They are in the region of complexes observed between $684-682 \mathrm{~cm}^{-1}$ and at $1150 \mathrm{~cm}^{-1}$, respectively. The absorption bands of $v(\mathrm{CH})$ are in the sodium salt at $3015-1191 \mathrm{~cm}^{-1}$, in the complexes they are in the ranges: $3023-2997 \mathrm{~cm}^{-1}$ and $1193-1186 \mathrm{~cm}^{-1}$.

Most bands in the IR spectrum can be attributed to the vibrations of 4-bpy. Their position and tentative assignments for the obtained species are made and given in Table 3. The infrared spectrum of free 4-bpy undergoes a chance upon coordination. The observations were made for 4-bpy absorption in the region $4000-600 \mathrm{~cm}^{-1}$. They are as follows: the band at $1588 \mathrm{~cm}^{-1}$ in pure 4-bpy is attributed to the $v(C C)$, $v(\mathrm{CN})$, and $v\left(\mathrm{CC}_{\mathrm{ir}}\right)$ vibrations - symmetry $A_{l}$, and it shifts toward higher frequency $\left(1612-1607 \mathrm{~cm}^{-1}\right)$. The band in the pure ligand at $1530 \mathrm{~cm}^{-1},(\mathrm{v}(\mathrm{CC})$, and $\mathrm{v}(\mathrm{CC})$ vibrationssymmetry $B_{1}$ ) in the IR spectra of complexes is very small and appears between 1550 and $1520 \mathrm{~cm}^{-1}$. The most characteristic band for 4-bpy is ring "breathing" mode. It shifts toward higher frequencies in comparison with free ligand. The band of free 4-bpy corresponding to ring deformation in plane observed at $608 \mathrm{~cm}^{-1}$ shifts to higher frequency after coordination with metal ion. In the regions of bands in the ranges of 1205-1092 and 962-672 $\mathrm{cm}^{-1}$, the spectra of absorption bands for synthesized complexes are poor.

Table 2 IR bands for $\mathrm{CHBr}_{2} \mathrm{COONa}$ and carboxylate groups in obtained complexes

\begin{tabular}{|c|c|c|c|c|c|c|}
\hline \multirow[t]{2}{*}{$\mathrm{CHBr}_{2} \mathrm{COONa}[14]$} & \multicolumn{5}{|c|}{ Complexes } & \multirow[t]{2}{*}{ Assignments } \\
\hline & $\mathrm{Ce}(\mathrm{III})$ & $\operatorname{Pr}(\mathrm{III})$ & $\mathrm{Nd}(\mathrm{III})$ & $\mathrm{Sm}(\mathrm{III})$ & $\mathrm{Eu}(\mathrm{III})$ & \\
\hline 3015 & 3020 & 3023 & 2997 & 2997 & 2998 & $v(\mathrm{CH})$ \\
\hline 1616 & 1667 & 1667 & 1669 & 1671 & $\begin{array}{l}1706 \\
1674\end{array}$ & $v_{\mathrm{as}}(\mathrm{COO})$ \\
\hline 1378 & 1386 & 1386 & 1386 & 1386 & 1386 & $v_{\mathrm{s}}(\mathrm{COO})$ \\
\hline 1191 & 1193 & 1192 & 1193 & 1191 & 1186 & $v(\mathrm{CH})$ \\
\hline 1148 & 1151 & 1150 & 1150 & 1150 & 1150 & $\delta(\mathrm{CCOO})$ \\
\hline 931 & 955 & - & - & - & - & $v(\mathrm{CC})$ \\
\hline 698 & 683 & 683 & 683 & 684 & 682 & $v_{\mathrm{s}}\left(\mathrm{CBr}_{2}\right)$ \\
\hline 238 & 282 & 281 & 283 & 285 & $\begin{array}{l}346 \\
288\end{array}$ & $\Delta v=v_{\mathrm{as}}-v_{\mathrm{s}}$ \\
\hline
\end{tabular}


Table 3 IR bands for free 4-bpy and 4-bpy in obtained complexes

\begin{tabular}{|c|c|c|c|c|c|c|}
\hline \multirow[t]{2}{*}{ 4-bpy [15] } & \multicolumn{5}{|c|}{ Complexes } & \multirow[t]{2}{*}{ Assignments } \\
\hline & $\mathrm{Ce}(\mathrm{III})$ & $\operatorname{Pr}(\mathrm{III})$ & $\mathrm{Nd}(\mathrm{III})$ & $\mathrm{Sm}(\mathrm{III})$ & $\mathrm{Eu}(\mathrm{III})$ & \\
\hline 1588 & 1608 & 1607 & 1609 & 1610 & 1612 & $\mathrm{v}(\mathrm{CC}), \mathrm{v}(\mathrm{CN}), \mathrm{v}\left(\mathrm{CC}_{\mathrm{ir}}\right), A_{l}$ \\
\hline 1530 & 1533 & 1530 & - & 1550 & 1520 & $v(\mathrm{CC}), \mathrm{v}(\mathrm{CN}) B_{1}$ \\
\hline 1488 & 1490 & 1490 & 1490 & 1490 & 1489 & $v(\mathrm{CC}), \mathrm{v}(\mathrm{CN})$ \\
\hline 1403 & 1413 & 1415 & 1413 & 1415 & - & $v(\mathrm{CC}), v(\mathrm{CN})$ \\
\hline 1328 & - & - & - & - & - & $v(\mathrm{CC}), v(\mathrm{CN})$ \\
\hline 1205 & 1226 & - & - & - & - & $\beta(\mathrm{CH})$ \\
\hline 1092 & - & - & - & - & - & $\beta(\mathrm{CH})$ \\
\hline 1072 & 1066 & 1066 & 1066 & 1066 & 1066 & $\beta(\mathrm{CH})$ \\
\hline 1037 & 1043 & 1045 & 1040 & 1040 & 1043 & „ring breathing” \\
\hline 988 & 1000 & 1001 & 1000 & 999 & 999 & „ring breathing” \\
\hline 962 & - & 960 & - & - & - & $\gamma(\mathrm{CH})$ \\
\hline 850 & 853 & 850 & - & - & - & $\gamma(\mathrm{CH})$ \\
\hline 810 & 809 & 808 & 808 & 808 & 807 & $\gamma(\mathrm{CH})$ \\
\hline 745 & 795 & - & - & - & - & $\gamma(\mathrm{CH})$ \\
\hline 733 & 716 & 716 & 717 & 718 & 718 & $\gamma(\mathrm{CH})$ \\
\hline 672 & - & - & - & - & - & $\gamma(\mathrm{CH})$ \\
\hline 608 & 622 & 622 & 623 & 621 & 621 & $\beta(\mathrm{CH})$ \\
\hline 572 & 596 & 595 & 595 & 595 & 596 & $\beta(\mathrm{CH})$ \\
\hline
\end{tabular}

i $r$ inter ring bands, $A_{l}$ symmetry $A_{1}, B_{1}$ symmetry $B_{1}$

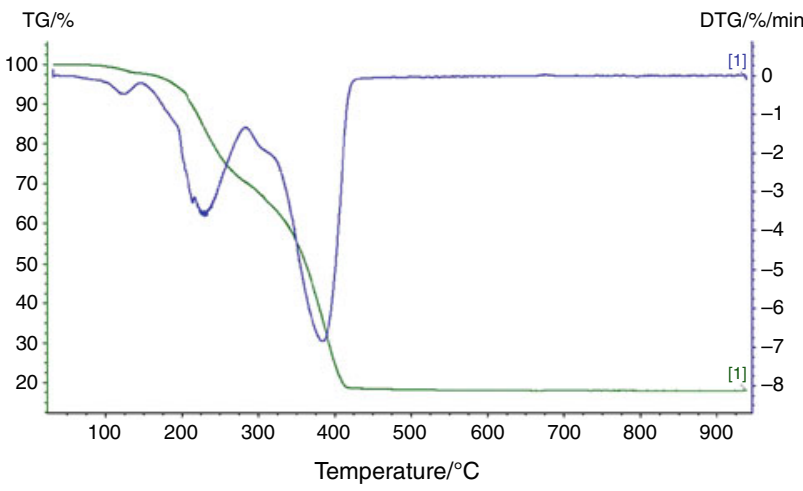

Fig. 2 TG and DTG curves of thermal decomposition of $\mathrm{Ce}$ (4-bpy) $\left(\mathrm{CHBr}_{2} \mathrm{COO}\right)_{3} \cdot \mathrm{H}_{2} \mathrm{O}$ recorded in air atmosphere; mass sample: $9.25 \mathrm{mg}$

In addition, a broad band in the water stretching region (ca $3450-3350 \mathrm{~cm}^{-1}$ ) appears for all the described complexes.

Thermogravimetric data in air

The TG-DTG methods were used to describe of thermal decompositions of the obtained complexes in air atmosphere. These thermolyses are complicated and difficult to interpretation. Decomposition of all compounds is multistage and overlapping processes. The first step of pyrolysis is dehydration. When the temperature rises, decomposition

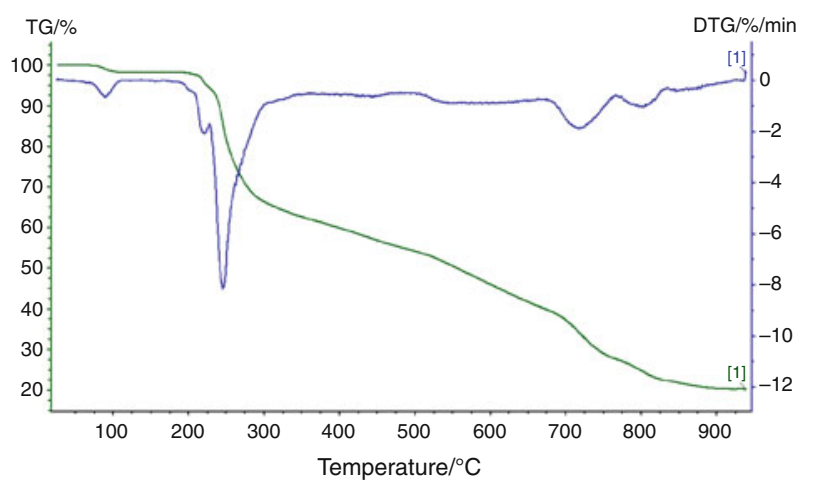

Fig. 3 TG and DTG curves of thermal decomposition of $\mathrm{Sm}(4 \text {-bpy })_{0.5}\left(\mathrm{CHBr}_{2} \mathrm{COO}\right)_{3} \cdot 2 \mathrm{H}_{2} \mathrm{O}$ recorded in air atmosphere; mass sample: $6.40 \mathrm{mg}$

of organic ligands begins, and several unidentified solid products are formed. Finally, decomposition products correspond to the suitable oxides. In general, the lines observed for $\mathrm{CeO}_{2}$ and $\mathrm{Ln}_{2} \mathrm{O}_{3}$ (Nd, Sm, Eu), $\mathrm{Pr}_{6} \mathrm{O}_{11}$ correspond to those reported in Powder Diffraction File [12]. Figures 2, 3, and 4 show profiles of TG and DTG of complexes of $\mathrm{Ce}(\mathrm{III}), \mathrm{Sm}(\mathrm{III})$ (as representative specie of isostructural group), and Eu(III). Results of thermal analysis are presented in Table 4.

$\mathrm{Ce}\left((4-b p y)\left(\mathrm{CHBr}_{2} \mathrm{COO}\right)_{3} \cdot \mathrm{H}_{2} \mathrm{O}\right.$ begins to decompose at $75^{\circ} \mathrm{C}$. It is associated with release water molecule (mass losses calculated $1.87 \%$ and found $1.9 \%$.). Decomposition of 


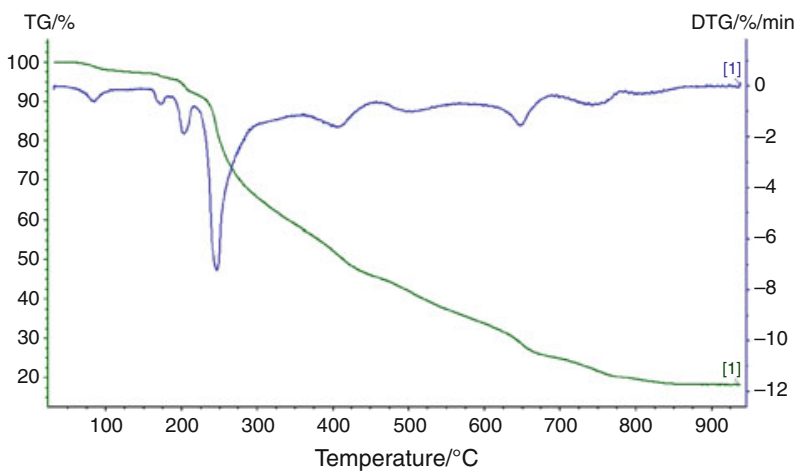

Fig. 4 TG and DTG curves of thermal decomposition of $\mathrm{Eu}(4-\mathrm{bpy})\left(\mathrm{CHBr}_{2} \mathrm{COO}\right)_{3} \cdot 2 \mathrm{H}_{2} \mathrm{O}$ recorded in air atmosphere; mass sample: $12.96 \mathrm{mg}$

organic ligands occurs immediately after dehydration at $150{ }^{\circ} \mathrm{C}$. It runs in a few overlapping steps with DTG peak at $230{ }^{\circ} \mathrm{C}$ with shoulder at $310^{\circ} \mathrm{C}$. The TG curve shows a rapid mass loss between $150-435{ }^{\circ} \mathrm{C}$ and very strong peak $385^{\circ} \mathrm{C}$ on DTG curve, as a result of total decomposition of organic ligands. At $435{ }^{\circ} \mathrm{C}$, pure $\mathrm{CeO}_{2}$ is formed as a final product (found: $18.0 \%$; calc.: $17.84 \%$ ).

Complex of $\operatorname{Pr}(\mathrm{III})$ dehydrates also in one step in temperature range of $65-150{ }^{\circ} \mathrm{C}$. Above $150{ }^{\circ} \mathrm{C}$, anhydrous unstable complex is formed. After dehydration, further pyrolysis (the destruction of dibromoacetate groups and oxidation of organic fragments) takes place. The DTG curve shows several peaks. A plateau on TG curve begins at $830{ }^{\circ} \mathrm{C}$ and corresponds to formation of pure $\operatorname{Pr}_{6} \mathrm{O}_{11}$ (found: $18.0 \%$; calc.: $18.80 \%$ ).

$\mathrm{Nd}$ (III) complex is dehydrated in two steps. At $85^{\circ} \mathrm{C}$, it loses one water molecule. Monohydrate specie is stable up to $175^{\circ} \mathrm{C}$. The next dehydration stage between
$175-200{ }^{\circ} \mathrm{C}$ takes place. When the temperature is raised further, in TG curve we observe mass loss, which is associated with degradation and combustion of organic ligands. Above $950{ }^{\circ} \mathrm{C}, \mathrm{Nd}_{2} \mathrm{O}_{3}$ appears very slowly. On DTG curve, peaks are observed at 235,715 , and $835^{\circ} \mathrm{C}$.

In the case of $\mathrm{Sm}$ (III) compound, the dehydration process occurs in two steps. At $75^{\circ} \mathrm{C}$, one water molecule is released. The second water molecule is not very well seen on TG curve, and so it is not interpreted. In the temperature range of $180-925{ }^{\circ} \mathrm{C}$, further thermolysis of this specie is observed with DTG peaks occurring at 220, 250, 715, and $800{ }^{\circ} \mathrm{C}$. Final solid product of decomposition is $\mathrm{Sm}_{2} \mathrm{O}_{3}$.

The complex $\mathrm{Eu}(4-\mathrm{bpy})\left(\mathrm{CHBr}_{2} \mathrm{COO}\right)_{3} \cdot 2 \mathrm{H}_{2} \mathrm{O}$ loses $1 \mathrm{~mol}$ of water above $65^{\circ} \mathrm{C}$. Next, in the range of $165-185^{\circ} \mathrm{C}$, the last water molecule is eliminated. When the temperature increases, the partial and total destructions of organic ligands take place. The DTG curve exhibits peaks at $205,250,410,500,650$, and $750{ }^{\circ} \mathrm{C}$. Horizontal mass level for $\mathrm{Eu}_{2} \mathrm{O}_{3}$ begins at $900{ }^{\circ} \mathrm{C}$.

TG-MS study for Ce(III) and Sm(III) complexes in air

To analyze the principal volatile products evolved during the dynamic thermal decomposition and fragmentation processes of $\mathrm{Ce}(\mathrm{III})$ and $\mathrm{Sm}(\mathrm{III})$ complexes, a couple TG-MS system was used. The determinations were carried out in dynamic air atmosphere.

For $\mathrm{Ce}(4-$ bpy $)\left(\mathrm{CHBr}_{2} \mathrm{COO}\right)_{3} \mathrm{H}_{2} \mathrm{O}$, major maxima for ion currents are observed in temperature range of $130-400{ }^{\circ} \mathrm{C}$. The first peaks for $\mathrm{OH}^{+}$and $\mathrm{H}_{2} \mathrm{O}^{+}(\mathrm{m} / \mathrm{z}=17,18)$ occurs around $135{ }^{\circ} \mathrm{C}$ and are connected with the dehydration of complex. Next, the $\mathrm{OH}^{+}$and $\mathrm{H}_{2} \mathrm{O}^{+}$are produced by oxidation of organic ligands (peaks at 260 and $350{ }^{\circ} \mathrm{C}$ ). In the

Table 4 Thermal decomposition data for obtained complexes in air atmosphere

\begin{tabular}{|c|c|c|c|c|c|}
\hline \multirow[t]{2}{*}{ Complex } & \multirow[t]{2}{*}{ Temperature range $/{ }^{\circ} \mathrm{C}$} & \multirow{2}{*}{$\begin{array}{l}\text { Principal peaks of DTG } \\
\text { temperature } /{ }^{\circ} \mathrm{C}\end{array}$} & \multicolumn{2}{|c|}{ Mass loss $/ \%$} & \multirow{2}{*}{$\begin{array}{l}\text { Intermediate and final } \\
\text { solid products }\end{array}$} \\
\hline & & & Calc. & Fund. & \\
\hline \multirow[t]{2}{*}{$\mathrm{Ce}(4$-bpy $)\left(\mathrm{CHBr}_{2} \mathrm{COO}\right)_{3} \cdot \mathrm{H}_{2} \mathrm{O}$} & $75-150$ & 125 & 1.87 & 1.9 & $\mathrm{Ce}(4-$ bpy $)\left(\mathrm{CHBr}_{2} \mathrm{COO}\right)_{3}$ \\
\hline & $150-435$ & 230,310 sh, 385 & 80.29 & 80.1 & $\mathrm{CeO}_{2}$ \\
\hline \multirow[t]{2}{*}{$\operatorname{Pr}(4-b p y)_{0.5}\left(\mathrm{CHBr}_{2} \mathrm{COO}\right)_{3} \cdot 2 \mathrm{H}_{2} \mathrm{O}$} & $65-150$ & 110 & 3.98 & 4.0 & $\operatorname{Pr}(4-b p y)_{0.5}\left(\mathrm{CHBr}_{2} \mathrm{COO}\right)_{3}$ \\
\hline & $150-830$ & $220-230,425,560,650,785$ & 77.22 & 78.0 & $\mathrm{Pr}_{6} \mathrm{O}_{11}$ \\
\hline \multirow[t]{3}{*}{$\mathrm{Nd}(4-\mathrm{bpy})_{0.5}\left(\mathrm{CHBr}_{2} \mathrm{COO}\right)_{3} \cdot 2 \mathrm{H}_{2} \mathrm{O}$} & $85-135$ & 110 & 1.98 & 2.0 & $\mathrm{Nd}(4-\mathrm{bpy})_{0.5}\left(\mathrm{CHBr}_{2} \mathrm{COO}\right)_{3} \cdot \mathrm{H}_{2} \mathrm{O}$ \\
\hline & $175-200$ & $170 \mathrm{sh}$ & 1.98 & 2.0 & $\mathrm{Nd}(4-\mathrm{bpy})_{0.5}\left(\mathrm{CHBr}_{2} \mathrm{COO}\right)_{3}$ \\
\hline & $>950$ & $235,715,835$ & 77.53 & & $\mathrm{Nd}_{2} \mathrm{O}_{3}^{*}$ \\
\hline \multirow[t]{2}{*}{$\mathrm{Sm}(4-\mathrm{bpy})_{0.5}\left(\mathrm{CHBr}_{2} \mathrm{COO}\right)_{3} \cdot 2 \mathrm{H}_{2} \mathrm{O}$} & $75-120$ & 85 & 1.97 & 2.0 & $\mathrm{Sm}(4-\mathrm{bpy})_{0.5}\left(\mathrm{CHBr}_{2} \mathrm{COO}\right)_{3} \cdot \mathrm{H}_{2} \mathrm{O}$ \\
\hline & $180-925$ & $220,250,715,800$ & 78.97 & 78.0 & $\mathrm{Sm}_{2} \mathrm{O}_{3}$ \\
\hline \multirow[t]{3}{*}{$\mathrm{Eu}(4-\mathrm{bpy})\left(\mathrm{CHBr}_{2} \mathrm{COO}\right)_{3} \cdot 2 \mathrm{H}_{2} \mathrm{O}$} & $65-110$ & 85 & 1.81 & 1.9 & $\mathrm{Eu}(4-\mathrm{bpy})\left(\mathrm{CHBr}_{2} \mathrm{COO}\right)_{3} \cdot \mathrm{H}_{2} \mathrm{O}$ \\
\hline & $165-185$ & 175 & 1.81 & 1.9 & $\mathrm{Eu}(4-\mathrm{bpy})\left(\mathrm{CHBr}_{2} \mathrm{COO}\right)_{3}$ \\
\hline & $185-900$ & $205,250,410,500,650,750$ & 78.69 & 78.2 & $\mathrm{Eu}_{2} \mathrm{O}_{3}$ \\
\hline
\end{tabular}

sh shoulder

* Very slowly 


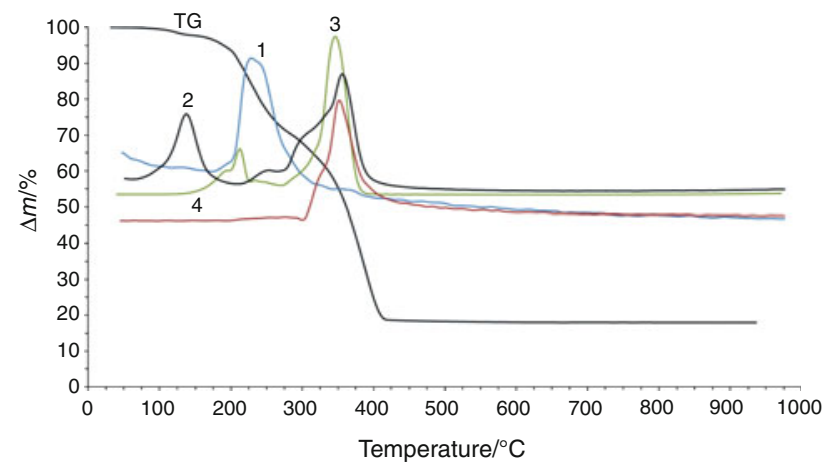

Fig. 5 TG curves for Ce(III) complex and ion current detected by the MS for mass fragments in air; $m / z: 1-15 ; 2-18,3-44$; and 4-80 with sensitivity of ion current: E-9, E-9, E-11, E-12, [A], respectively; mass sample: $8.50 \mathrm{mg}$

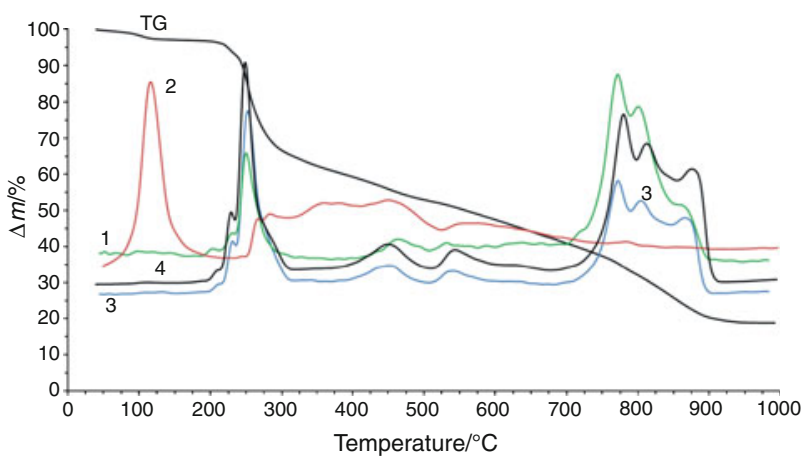

Fig. 6 TG curve for Sm(III) complex and ion current detected by the MS for mass fragments in air; $m / z: 1-12 ; 2-18 ; 3-30$, and 4-44 with sensitivity of ion current: E-9, E-8, E-11, E-9 [A], respectively, mass sample $12.70 \mathrm{mg}$

range of $190-350{ }^{\circ} \mathrm{C}$, several gaseous products start to liberate. The profiles of $\mathrm{CO}_{2}^{+}(\mathrm{m} / \mathrm{z}=44,45,46)$ exhibit maxima at $190^{\circ}, 210^{\circ}$, and very high intensity at $345^{\circ} \mathrm{C}$. The bromide species: $\mathrm{Br}^{+}, \mathrm{HBr}^{+}, \mathrm{CH}_{2} \mathrm{Br}^{+}$, and $\mathrm{Br}_{2}^{+}$ $(\mathrm{m} / \mathrm{z}=80,93,94$, and 160, respectively) appear between 230-350 ${ }^{\circ} \mathrm{C}$. The mass spectrometer detected also the fragments of $m / z=15\left(\mathrm{CH}_{3}^{+}\right.$or $\left.\mathrm{NH}^{+}\right), 30\left(\mathrm{CH}_{2} \mathrm{O}^{+}\right.$or $\left.\mathrm{NO}^{+}\right), 46\left(\mathrm{NO}_{2}^{+}\right), 48\left(\mathrm{H}_{2} \mathrm{NO}_{2}^{+}\right), 60\left(\mathrm{C}_{2} \mathrm{H}_{4} \mathrm{O}_{2}^{+}\right)$, and traces of other ion signals. Maximum rates of formation of $\mathrm{CH}_{3}^{+}$ (or $\mathrm{NH}^{+}$) and $\mathrm{CH}_{2} \mathrm{O}^{+}$(or $\mathrm{NO}^{+}$) are observed at 235 and at $360{ }^{\circ} \mathrm{C}$, respectively. The evaluation of all gaseous products is terminated at about $400{ }^{\circ} \mathrm{C}$. TG-MS data of select ion currents of decomposition for $\mathrm{Ce}(\mathrm{III})$ compound is shown in Fig. 5.

In contrast to the $\mathrm{Ce}(\mathrm{III})$ compound, emission of the principal volatile product during thermal decomposition and fragmentation processes for the $\mathrm{Sm}$ (III) compound comes to an end at about $900{ }^{\circ} \mathrm{C}$. The peaks of $\mathrm{H}_{2} \mathrm{O}^{+}$and $\mathrm{OH}^{+}$connected with dehydration occur at about $110{ }^{\circ} \mathrm{C}$. The peaks of these ions appear also in the regions of $255^{\circ}-510^{\circ}$ and 510-775 ${ }^{\circ} \mathrm{C}$. The ion signal intensities of $\mathrm{C}^{+}, \mathrm{CO}_{2}^{+}$, and its isotopes have centers at $210{ }^{\circ} \mathrm{C}$ (very low intensity), 225 , $250,450,530,765,800$, and $865^{\circ} \mathrm{C}$; also the profiles of $\mathrm{CH}_{2} \mathrm{O}^{+}$or $\mathrm{NO}^{+}(\mathrm{m} / \mathrm{z}=30)$ appear. This suggests decomposition and oxidization of organic ligands and the burning of the organic residues. The major ion signals containing bromide: $\mathrm{Br}^{+}, \mathrm{HBr}^{+}, \mathrm{CH}_{2} \mathrm{Br}^{+}$, and $\mathrm{CH}_{3} \mathrm{Br}^{+}$(and its isotopes) have several centers. The first maximum for all these fragments are observed in the temperature range: 235-290 ${ }^{\circ} \mathrm{C}$. In addition, further maxima of $\mathrm{Br}^{+}$ions occur at ca. 460 and $850{ }^{\circ} \mathrm{C}$. The strong peak of $\mathrm{CH}_{3}^{+}$or $\mathrm{NH}^{+}$ $(m / z=15)$ was monitored at $250^{\circ} \mathrm{C}$. The mass spectrometer detected also the traces of amounts of fragments $m / z=60$. Figure 6 presents correlation of some ion currents on TG curve of $\mathrm{Sm}$ (III) complex in air atmosphere.

\section{Conclusions}

On the basis of the present and previous results [4-6], it may be stated that mixed ligand complexes of $\mathrm{La}$ (III) and $\mathrm{Ce}$ (III) with 4-bpy and dibromoacetates are formed with empirical formulae: $\mathrm{Ln}(4-\mathrm{bpy})\left(\mathrm{CHBr}_{2} \mathrm{COO}\right)_{3} \cdot \mathrm{H}_{2} \mathrm{O}$. It is similar as was obtained (in the same experimental conditions) in the series of lanthanide(III) complexes $\mathrm{Ln}$ (III) $=\mathrm{Y}, \mathrm{La} \rightarrow \mathrm{Eu}$ (without Pm) with 4-bpy and dichloroacetates [4-6]. On the other hand, the compounds of $\operatorname{Pr}(\mathrm{III}), \mathrm{Nd}(\mathrm{III}), \mathrm{Sm}(\mathrm{III})$ with 4-bpy and dibromoacetates are of the following type: $\mathrm{Ln}$ (4-bpy $)_{0.5}\left(\mathrm{CHBr}_{2} \mathrm{COO}\right)_{3} \cdot 2 \mathrm{H}_{2} \mathrm{O}$. The synthesized complexes containing 4-bpy and dibromoacetates are small crystalline. and isostructural in two groups: $\mathrm{La}(\mathrm{III})$ [11], $\mathrm{Ce}(\mathrm{III})$; and $\mathrm{Pr}(\mathrm{III}), \mathrm{Nd}(\mathrm{III}), \mathrm{Sm}(\mathrm{III})$.

Changes observed in the IR spectra of complexes indicate that title ligands coordinate to lanthanide ions $[2,4,5,16,21-23]$. Probably, the large electronegativity of the substitute bromide atoms in carboxylate group suggests monodentate type of coordination of this ligand.

Thermal decompositions for all the series of discussed compounds in flow of dynamic air atmosphere are of multistage and overlapping processes. The initial temperatures of dehydration processes in the series of lanthanide complexes with 4-bpy and dichloro- or dibromoacetates (where $\mathrm{Ln}(\mathrm{III})=\mathrm{Y}, \mathrm{La} \rightarrow$ Eu without $\mathrm{Pm}$ ) do not change regularly with the ionic potential of elements. For compounds $\mathrm{Ln}(4$-bpy $)\left(\mathrm{CHCl}_{2} \mathrm{COO}\right)_{3} \cdot \mathrm{H}_{2} \mathrm{O}$ (where $\mathrm{Ln}(\mathrm{III})=\mathrm{Y}$, $\mathrm{La} \rightarrow$ Eu without $\mathrm{Pm}$ ) [4-6], the specie of $\operatorname{Pr}(\mathrm{III})$ is the least thermally stable. It starts to lose water molecule at $80{ }^{\circ} \mathrm{C}$, where the most stable compound is $\mathrm{Eu}(4-\mathrm{bpy})$ $\left(\mathrm{CHCl}_{2} \mathrm{COO}\right)_{3} \cdot \mathrm{H}_{2} \mathrm{O}\left(100{ }^{\circ} \mathrm{C}\right)$. In the case of lanthanide compounds with 4-bpy and dibromoacetates complex of $\mathrm{La}(\mathrm{III})$ [11] is the most stable because its dehydration begins at $100{ }^{\circ} \mathrm{C}$, whereas $\mathrm{Y}(4-\mathrm{bpy})_{1.5}\left(\mathrm{CHBr}_{2} \mathrm{COO}\right)_{3} \cdot 3 \mathrm{H}_{2} \mathrm{O}$ $\left(55^{\circ} \mathrm{C}\right)[11]$ is the least. In general, the obtained results suggest that species including dichloroacetate ligands are 
stabler than those containing dibromoacetates. As the final solid products of thermal decomposition are the proper lanthanide oxides.

The TG-MS system was used to determinate volatile products of thermal decomposition of $\mathrm{Ce}$ (4-bpy) $\left(\mathrm{CHBr}_{2} \mathrm{COO}\right)_{3} \cdot \mathrm{H}_{2} \mathrm{O}$ and $\mathrm{Sm}(4-\mathrm{bpy})_{0.5}\left(\mathrm{CHBr}_{2} \mathrm{COO}\right)_{3} \cdot 2 \mathrm{H}_{2} \mathrm{O}$ complexes in dynamic air atmosphere. The first process is dehydration containing elevation of water. The gas evolved contains ion currents of $\mathrm{H}_{2} \mathrm{O}^{+}$and $\mathrm{OH}^{+}(\mathrm{m} / \mathrm{z}=17,18)$. When the temperature rises partial and total decomposition of organic ligands takes place. The major ion signal intensities of $\mathrm{H}_{2} \mathrm{O}^{+}, \mathrm{OH}^{+}, \mathrm{C}^{+}, \mathrm{CH}_{3}^{+}$or $\mathrm{NH}^{+}, \mathrm{CO}_{2}^{+}$, and $\mathrm{CH}_{2} \mathrm{O}^{+}$or $\mathrm{NO}^{+}$ appear. In addition, maximum signals containing bromide are observed. Emission of gaseous products in particular steps of thermal decomposition of $\mathrm{Ce}$ (III) and Sm(III) complexes correspond with mass losses on TG curves.

Acknowledgments The helpful assistance of MSc Mirosława Markiewicz is gratefully acknowledged.

Open Access This article is distributed under the terms of the Creative Commons Attribution License which permits any use, distribution, and reproduction in any medium, provided the original author(s) and the source are credited.

\section{References}

1. Czylkowska A, Markiewicz M. Coordination behaviour and thermolysis of some rare-earth complexes with 4,4'-bipyridine and di or trichloroacetates. J Therm Anal Calorim. 2010;100:717-23. doi: 10.1007/s10973-009-0182-5.

2. Czylkowska A, Czakis-Sulikowska D, Kruszyński R, Markiewicz M. Synthesis, crystal structure and other properties of the complexes of $\mathrm{Er}(\mathrm{III}), \mathrm{Yb}$ (III) and $\mathrm{Lu}$ (III) with 4,4'-bipyridine and dichloroacetates. Struct Chem. 2009;21:415-23. doi:10.1007/s11224-009-9545-6.

3. Czylkowska A, Czakis-Sulikowska D, Kaczmarek A, Markiewicz M (2010) Thermal behavior and other properties of $\operatorname{Pr}(\mathrm{III}), \mathrm{Sm}(\mathrm{III})$, $\mathrm{Eu}(\mathrm{III}), \mathrm{Gd}(\mathrm{III}), \mathrm{Tb}(\mathrm{III})$ complexes with $4,4^{\prime}$-bipyridine and trichloroacetates. J. Therm. Anal. Calorim. doi: 10.1007/s10973-0111462-4.

4. Czylkowska A, Kruszyński R, Czakis-Sulikowska D, Markiewicz M. Coordination polymer of lanthanum: synthesis, properties and crystal structure of $\left[\mathrm{La}\left(4,4^{\prime} \text {-bipyridine }\right)\left(\mathrm{CCl}_{2} \mathrm{HCOO}\right)_{3}\left(\mathrm{H}_{2} \mathrm{O}\right)\right]_{n}$. J Coord Chem. 2007;60:2659-69. doi:10.1080/00958970701299550.

5. Kruszyński R, Czylkowska A, Czakis-Sulikowska D. A novel carboxylic coordination polymer of samarium(III): [ $\mathrm{Sm}\left(\mathrm{H}_{2} \mathrm{O}\right)\left(4,4^{\prime}-\right.$ bipyridine $\left.)\left(\mathrm{CCl}_{2} \mathrm{HCOO}\right)_{3}\right]_{n}$. J Coord Chem. 2006;59:681-90. doi: 10.1080/00958970500345356.

6. Czakis-Sulikowska D, Czylkowska A, Markiewicz M. Synthesis, characterization and thermal decomposition of yttrium and light lanthanides with 4,4'-bipyridine and dichloroacetates. Polish J Chem. 2007;81:1267-75.
7. Czakis-Sulikowska D, Czylkowska A, Markiewicz M, Frajtak M. Synthesis and properties of complexes of Gd(III), Tb(III), Ho(III) and Tm(III) with 4,4'-bipyridine and dichloroacetates. Polish J Chem. 2009;83:1893-901.

8. Czylkowska A. New complexes of heavy lanthanides with 4,4'bipyridine and trichloroacetates; Synthesis, thermal and other properties. J. Therm. Anal. Calorim. 2012;110:1299-1308.

9. Czylkowska A, Kruszyński R, Kaczmarek A, Markiewicz M. Synthesis and crystal structure of compounds $\left[\mathrm{Ln}\left(\mathrm{H}_{2} \mathrm{O}\right)_{8}\right]^{3+} \cdot 4 \mathrm{CCl}_{3}$ $\mathrm{COO}^{-} \cdot 4 \mathrm{H}_{2} \mathrm{O} \cdot 2(4-\mathrm{bpy}) \cdot(4-\mathrm{bpyH})^{+}$. J Chem Struct. 2012;53(5): 966-70.

10. Kokonov JV, Segal EJ. Thermal decomposition of complexes of neodynium and erbium with 1,10-phenathroline and 2,2'-bipyridyl. Rev Roum Chim. 1971;16:1647-50.

11. Czylkowska A, Markiewicz M. Synthesis, thermal behavior and other properties of $\mathrm{Y}(\mathrm{III})$ and $\mathrm{La}(\mathrm{III})$ complexes with $4,4^{\prime}$ bipyridine and trichloro- or dibromoacetates. J Therm Anal Calorim. 2012. doi:10.1007/s10973-012-2454-8.

12. Powder Diffraction File, PDF-2, release 2004.The International Centre for Diffraction Data (ICDD) 12 Campus Boulevard, Newton Square, PA, USA.

13. Geary WI. The use of conductivity measurements in organic solvents for the characterization of coordination compounds. Coord Chem Rev. 1971;7:81-122. doi:10.1016/S0010-8545(00) 80009-0.

14. Spinner E. The vibration spectra of some substituted acetate ions. J Chem Soc. 1964;4217.

15. Pearce CK, Grosse DW, Hessel W. Effect of molecular structure on infrared spectra of six isomers of bipyridine. Chem Eng Data. 1970;15:567-70. doi:10.1021/je60047a042.

16. Nakamoto K. Infrared and Raman spectra of inorganic and coordination compounds. New York: Wiley; 2009.

17. Łyszczek R. Comparison of thermal properties of lanthanide trimellitates prepared by different methods. J Therm Anal Calorim. 2008;93(3):833-8. doi:10.1007/s10973-008-9203-z.

18. Manhas BS, Trikha AK. Relationships between the direction of shifts in the carbon-oxygen stretching frequencies of carboxylato complexes and the type of carboxylate coordination. Indian $\mathbf{J}$ Chem. 1982;59:315-9.

20. Ferenc W, Cristóvão B, Sarzyński J, Sadowski P. Complexes of the selected transition metal ions with 4-methoxycinnamic acid. J Therm Anal Calorim. 2012;110:739-48. doi:10.1007/s10973-011-1935-5.

21. Ye HM, Ren N, Li H, Zhang JJ, Sun SJ, Tian L. Synthesis, crystal structure and thermal decomposition kinetics of complex $\left[\mathrm{Nd}(\mathrm{BA})_{3}\right.$ bipy $]_{2}$. J Therm Anal Calorim. 2010;101:205-11. doi:10.1007/ s10973-009-0428-2.

22. Rzączyńska Z, Kula A, Sienkiewicz-Gromiuk J, Szybiak A. Synthesis, spectroscopic and thermal studies of 2,3-naphthalenedicarboxylates of rare earth elements. J Therm Anal Calorim. 2011;103:275-81. doi:10.1007/s10973-010-0927-1.

23. Łyszczek R. Hydrothermal synthesis, thermal and luminescent investigations of lanthanide(III) coordination polymers based on the 4,4'-oxybis(benzoate) ligand. J Therm Anal Calorim. 2012;108:1101-10. doi:10.1007/s10973-011-1987-6. 